\title{
The Influence of the Environment on the Tourism Enterprises Innovativeness
}

\author{
Elżbieta Szymańska* \\ Bialystok University of Technology, Poland. \\ * Corresponding author. E-mail: e.szymanska@pb.edu.pl \\ Manuscript submitted April 25, 2017; accepted October 3, 2017. \\ doi: 10.17706/ijeeee.2018.8.2.122-129
}

\begin{abstract}
The aim of this article is to indicate exogenous factors which affect the innovativeness of the tourism companies.

The Author attempts to identify the main factors by creating a model, subsequently verifying the theoretical assumptions in the context of empirical studies and comparing the results of her own research with those carried out by other researchers. In order to achieve the objective, the questionnaire method was used and comparison analysis.

The paper presents the results of two conducted surveys: performed on a group of 215 tourism enterprises (hotels, travel agencies and transport enterprises) and the survey performed on a group of 42 innovative tour operators. The study showed the following - there are determinants of innovativeness in the microeconomic environment of respondents. Customers play a major role but the cooperation with other firms is very important, too. Innovation policy, taking into account the foresight approach to the service sector, can contribute to the innovation of these companies, and the whole economy.

This study presents the original results with implications for both research and innovation policy. Contribution to the development of the science theory is a model which reflects the division of these factors into those from the micro environment and the macro environment of a tourism company.
\end{abstract}

Key words: Innovations, innovation policy, service enterprises, tourist enterprises, foresight, exogenous innovativeness factors.

\section{Introduction}

Innovation is perceived as the major driver of economic growth [1]. Therefore, the innovation issues have been discussed in many publications. The most important publications include those by J.A. Schumpeter [2], considered to be the father of innovation theory, along with his outstanding work The Theory of Economic Growth [2]. The Author adopts here the classical definition of innovation which was proposed in the early 20th century by Joseph A. Schumpeter, called the father of innovation theory. According to him, innovation is [2]: the launch of the production of new products or the improvement of existing ones, the introduction of a new or improved production technology, the use of a new manner of sales or purchase, the opening of a new market, the use of new resources or intermediate products, the introduction of changes in the organisation of production.

The research problem which the Author undertakes to address in this paper is the innovativeness of service enterprises on the example of tourism business. The aim of this study is to indicate exogenous factors which affect the enhancement of corporate innovativeness on the example of tourism enterprises. 
The study presents the original results with implications for both research and practice.

\section{The Literature Review}

Innovation policy is an important factor in economic development and is the subject of numerous research studies conducted by: Cruysen and Hollanders [3], Szymańska [4], Żukrowska [5], conducted by OECD and European Commission. The OECD documents, starting with the Oslo Manual [6], and continued by other publications, recognized that service enterprises can be innovative in their own right [7]. Even though the process of innovation and the kinds of innovation may be different from those traditionally associated with manufacturing and other primary activities [8], [9]. This difference ensues from three major reasons [8]. Firstly, services are a process. Secondly, services are interactive. Thirdly, the service sector is one of extreme diversity. Moreover, in production enterprises innovativeness primarily depends on R\&D outlays and the application of modern technologies [10]. Wide research on the factors affecting service enterprises was carried out by Gallouj [8], Gallouj \& Savona [11], Gault [12], Baczko [13] and Szymańska [14], [15]. The direction of the research was set out by the publications of the OECD and Eurostat, which appeared in the series called Frascati Family. The Oslo Manual [6] should be considered a milestone in research on service innovation.

In contrast to production enterprises, researchers consider the following exogenous factors affecting the innovativeness of service enterprises (innovation determinants) to be the most important:

- customer dialogue [16], users - customers [17];

- the participation in clusters [18] or other non-governmental organisations [14];

- the membership in a network, primarily international ones [19];

- the cooperation with different institutions, including universities [20] and commercial consulting companies [21].

Anne-Mette Hjalager [22] should be considered the precursor of research on innovation in the tourism industry. In her publications, the researcher addressed many important issues related to the innovation. She presented her research on the innovation patterns in sustainable tourism [23], cultural tourism innovation systems [24] and innovation in tourism in a welfare state perspective [25]. Her research on these problems was continued by other researchers as Hall and Williams [26] and Szymańska [14], who tried to determine the manifestations of innovation in the tourism sector. The innovative form of marketing in tourism is also an interesting problem [27]. Tourism sector includes: transportation, accommodation, tourism attractions, beverage and gift shops. The OECD also explored innovation and growth drivers in tourism [28] and laid down the foundations for the research on innovation in the economy.

To sum up, a lot of articles published in the last decade referred to the service innovations, however, the area is still insufficiently recognized.

\section{Methods and the Course of the Research}

The research on the exogenous factors affecting the innovativeness of service enterprises was carried out in two rounds. The first round was conducted in 2009 and included innovations implemented within previous 3 years. Population was 5007 statistical units, including: 2228 tour operators 2301 hotels and 478 passenger transport companies [29]. Survey questionnaires were sent by e-mail or handed directly on paper 890 tourism industry players. For the study sample was selected 215 firms, among which 3 layers were distinguished: 98 tour operators, 100 hotels and 17 passenger transport companies.

The second round of research was limited to most innovative tour operators. Research in the qualitative part based on 42 in-depth interviews and a quantitative on a sample of $n=2994$ companies from 3074 entities registered in the Register of Tour Operators [29]. In Round I of the surveys, the respondents were 
able to repeatedly choose answers from among 14 exogenous variables. A binary scale (yes-no) was used in the questions contained in the survey questionnaire and during a telephone interview. The purpose of the questionnaire used in the survey was to identify and evaluate exogenous variables which drove innovation at the enterprises surveyed. The choice options were arranged in an order of growing importance, patterned on a 5-point Likert scale, from 0 - nonexistent, 1 - unimportant, 2 - little importance, to 5 - of key significance for the implementation of innovations. The point of departure were 14 variables used in the Round I survey, which had been specified by adding additional questions. As a total, 26 variables were proposed. They were set in a table in the form of a semi-open cafeteria, with the possibility of proposing additional variables.

There was a basic difference between the samples selected in the two rounds. The difference was that in the course of the Round I survey innovative firms were identified from among the respondents which participated in it. The sample was representative of the population of tourism enterprises in Poland. In turn, in Round II all the respondents were assessed as innovative firms and this was the condition for their participation in the survey. Round I of the surveys was indispensable to enable the implementation of Round II, since in its course the types of innovation occurring on the tourism market were identified [14].

\section{The Exogenous Factors Affecting the Innovativeness of Enterprises - The Construction of a Model}

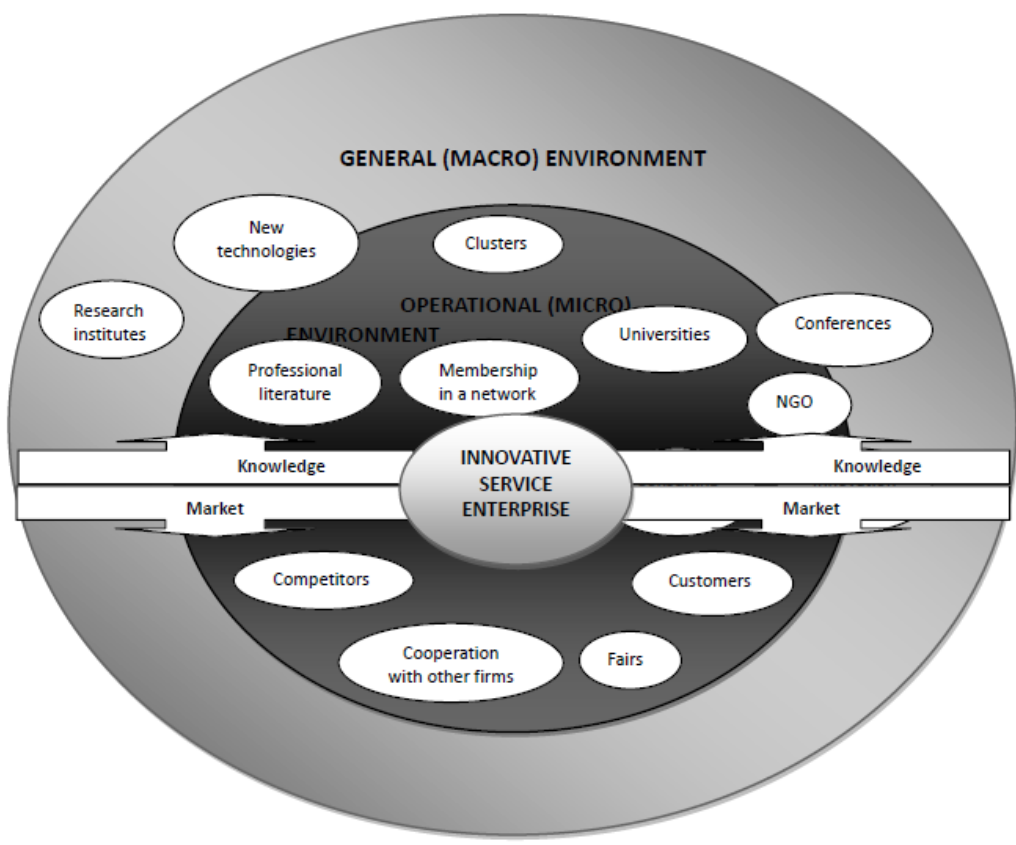

Fig. 1. A model of the factors which affect the innovativeness of a service enterprise.

Source: Own elaboration based on: Janasz, W. and Kozioł K. (2007), Determinanty działalności innowacyjnej przedsiębiorstw [The Determinants of the Corporate Innovation Activity], PWE, Warsaw [30]; North, D. C. (2005), Understanding the Process of Economic Change, Princeton University Press, Princeton and Oxford [31].

The point of departure for the construction of a model was the proposal for dividing the factors affecting the innovativeness of enterprises into two basic groups: the endogenous and those situated outside of enterprises, i.e. the co-called exogenous factors. In this study, the latter ones were considered.

One can speak of many factors in the business environment of a company which influence the innovation 
process. According to Janasz and Kozioł [30], it consists of two planes: the nearer one, i.e. the operational environment or the micro environment, and the farther one, i.e. the general environment or the macro environment. The Author also distinguished factors related to knowledge and the market. The construction of an economic model entails the need to use certain simplifications, which make it impossible to include in the model all the variables present in the economic reality (all the more so as a real, dynamic economic and political system is not fully cognisable); still, it does allow for the identification of the most important phenomena and processes [31]. The proposed model is shown in Fig. 1.

The model includes a total of 14 proposed factors, of which 9 have been placed in the knowledge area, with the others assigned to the market area. The group of factors from the general environment includes research institutes and conferences. Most of the factors is in the operational environment. These include in the knowledge area: professional literature, clusters, membership in a network and consulting firms. In the area of market can be found clients, competitors, sectoral fairs and cooperation with other firms. The variables that occur in both the near and far surroundings were placed on the border of these areas. The following factors are at the interface of these areas: NGOs (international and national non-governmental organisations, including tourist organisations), universities, new technologies and innovation policy.

A certain doubt arises as to the assignment of individual variables to the nearer or farther environments. This concerns the cooperation with different bodies, including nongovernmental organisations and higher education institutions. Anyway, it seems that the assignment of a given variable to the nearer or farther field of the model is not really important for the essence of the considerations, since it is the very presence and significance of a given factor that are important, rather than its situation.

\section{Research Results}

The research done on two samples demonstrates substantial differences in the use of exogenous factors affecting the innovativeness of the enterprises surveyed. The figure given below allows for these results to be compared. Certain simplifications were applied here to facilitate comparisons. Specifically, from among the innovation factors indicated by innovative tour operators, only those that had been available for selection by respondents in the earlier survey were chosen for the presentation. As a total, the structure ratios are shown in Fig. 3 for 14 independent variables. In addition there are four examples of research institutions that respondents chose to study: OECD, Eurostat, Institute of Tourism and Central Statistical Office (GUS).

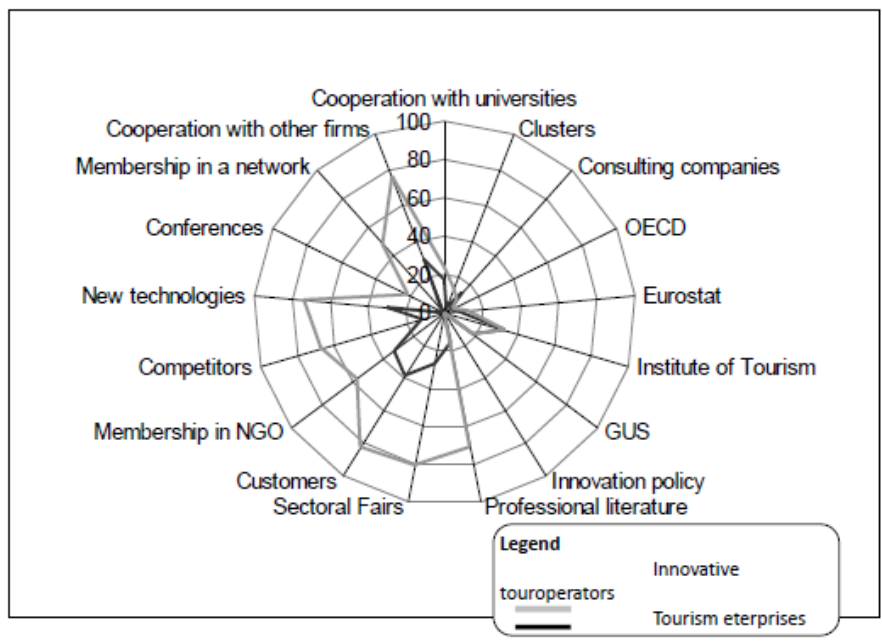

Source: Own elaboration based on the surveys performed.

Fig. 2. Comparison of the extent of the use of exogenous factors in the innovation process at the enterprises surveyed [percentage data]. 
Fig. 2 above shows a significant asymmetry (a slant to the left) of both of the web threads. This indicates the leading role of five independent variables: customers, the participation in sectoral fairs, new technologies, cooperation with other firms and nongovernmental organisations (NGOs). In turn, in the case of innovative tour operators, such a role is also played by another two variables: professional literature and competitors. Moreover, the shape which the internal thread takes resembles that of the external thread. Innovative enterprises more often use the exogenous innovation factors indicated than average tourist firms do. The Author also drew such conclusions from her own research [14] (Szymańska, 2009). There is a deviation from this rule only in the case of the use of consulting companies, where a slight difference in favour of tourism enterprises occurs. In both cases, the results coincide. This is the case with the use of information from the Central Statistical Office (19\%) and the materials of the Institute of Tourism (33\%); the latter should be treated as a research institute which specialises in surveys on the domestic tourism market.

In both surveys, the key significance should be attributed to customers which were indicated by $83 \%$ respondents, while in the case of three groups of tourism enterprises they were indicated by $39 \%$ respondents in the earlier survey. It can be said that the participation in sectoral fairs is very stimulating for the innovativeness of the enterprises surveyed, since they also took an important, fourth position in the earlier survey (27\%). In turn, in relation to radical innovation processes, $81 \%$ respondents marked their positive impact. An important role in these processes is played by sectoral nongovernmental organisations to which the respondents in both survey groups belong. Thus, 34\% of the tourism enterprises surveyed earlier cooperated with organisations of this type or were their members, which they considered favourable for creating innovations. In view of the suggested significant role of these organisations in the innovation process, several variables relating to these issues were specified in the more recent survey. In addition to the membership in organisations, which was indicated by $57 \%$ of tour operators (Fig. 2), consideration was given to the cooperation with the domestic $(21 \%)$ and international $(10 \%)$ nongovernmental organisations. There are substantial differences in the scope of the imitation of competitors. Whereas more than one tenth (12\%) of tourism enterprises follow the patterns set by competitive firms, two of three respondents (67\%) among innovative firms admit to having creatively followed their competitors.

It is interesting to note the cooperation with higher education institutions indicated by $24 \%$ of tour operators, while another $31 \%$ drew on their publications in the innovation process, and, in turn, in the survey on three groups of tourism enterprises $17 \%$ of those surveyed declared that they cooperated with higher education institutions.

In the survey on the group of innovative tour operators, they often indicated a significant role of the cooperation with the domestic enterprises from the same sector $(76 \%)$, which was not considered as falling into the area of "creative imitation of competitors". The cooperation with foreign sectoral enterprises was almost as highly appreciated (69\% of indications). These results are different from those obtained in the earlier survey, which did not indicate a direct dependence between the level of innovativeness of travel agencies (measured by the number of innovations introduced over 3 years) and international cooperation. In contrast, the results obtained in the case of the other enterprises surveyed (hotels and passenger transport enterprises) confirmed this type of dependence [14] (cf. Szymańska, 2009). The average score for the cooperation with other firms was 30\% (for 215 respondents). The present survey demonstrates that innovative enterprises are involved in extensive cooperation with other firms from the same sector, both domestic and foreign.

Many variables which stimulate innovativeness can be found here, with most of them existing in the operational environment of the enterprise.

\section{Conclusions}

Based on the literature review and the results of the research should be considered that there is no innovation policy in Poland. There are some initiatives which should be include in innovation policy, for example: expennditure on R\&D, donations on innovations (by using UE founds), institutions supporting 
innovativeness. But the lack of coordination of these activities, which would consist in the homogeneous (coherent) innovation policy.

In general, the present considerations regarding the variables inducing radical innovation processes at tour operators confirmed the results of the previous survey on the innovativeness of tourism enterprises, as a result of which the hypothesis envisaging higher innovativeness of enterprises drawing on diversified exogenous sources for transfers of knowledge was validated.

Detailed conclusions and comparisons with the results of the surveys carried out by other researchers are presented below:

- customers are the most important factor affecting innovative tourism enterprises, producing the structure ratios of 0.39 in Round I and 0.83 in Round II (importantly, with an average score of 3.75);

- the respondents attributed relatively large significance to the participation in sectoral fairs $(27 \%$ in Round I and $81 \%$ in Round II, with 3.25 average score - more than moderate importance), which seem to inspire new ideas;

- it is important to note the high appreciation in Round II of the benefits ensuing from the cooperation with other enterprises from the same sector, both domestic (76\%, with 2.22 average score) and foreign (69\%, 1.71 average score);

- the membership in a network seems to have a large effect on the innovativeness of service enterprises, as confirmed by the survey on innovative tour operators, almost half of which (47\% with average score 3.33 - more than moderate importance) emphasised the importance of this factor. Similarly, its significance was stressed by Marion Frenz and Grazia Letto-Gillies [19] (2009);

- among the variables stimulating innovative processes, $76 \%$ of respondents in Round II indicated new technologies, attributing to them slightly greater than moderate significance with the average score 3.16 .

In addition to the conclusions regarding the factors affecting the innovativeness of service enterprises, the following recommendations can also be formulated concerning the research methodology and the innovation policy. There is a clear shortage of research on the factors affecting the innovativeness of service enterprises on which, after all, the Polish and European economies depend. Certain doubts arise concerning the assignment of the particular variables to the nearer and farther environments; some difficulties are also encountered in their classification as factors related to the market or to knowledge. An example of this is the national innovation policy which includes budget outlays on research and development.

The studies conducted by Author also made it possible to develop recommendations regarding future research according to factors of service innovativeness.

Conclusions and recommendations should contribute to the development of innovation theory and be applied in the economic practice of not only tourism enterprises, but also other service enterprises.

\section{Acknowledgements}

The research were supported by Bialystok University of Technology (Politechnika Białostocka): S/WZ/5/2015

\section{References}

[1] Samuelson, P. A., \& Nordhaus, W. D. (2012). Ekonomia [Economics]. REBIS, Poznań.

[2] Schumpeter, J. A. (1960). The Theory of Economic Development. PWN, Warszawa.

[3] Cruysen, A., \& Hollanders, H. (2008). Are specific policies needed to stimulate innovation in services?, INNO Metrics 2007 report. European Commission, Directorate-General for Enterprise and Industry, Brussels.

[4] Szymańska, E. (2012). Pro-innovation policy in Poland. The Drivers of Consolidation of the R\&D Sector. Publishing House of the Bialystok University of Technology, Białystok. 
[5] Żukrowska, K., (2006). International coordination of politics: fields and methods. Economic Papers, 40.

[6] Oslo, M. (2005). OECD/European Communities/Eurostat, Paris.

[7] Metcalfe, J. S., \& Miles, I. (2012). Innovation Systems in the Service Economy: Measurement and Case Study Analysis. Springer, UK.

[8] Gallouj, F. (2002). Innovation in services and the attendant old and new myths. The Journal of Socioeconomics, 31(2), 137-154.

[9] Tether, B. S. (2005). Do services innovate (differently)? Insights from the European innobarometer survey. Industry and Innovation, 12(2), 153-184.

[10] Aw, B. Y., Roberts, V. \& Xu, D. Y. (2011). R\&D investment, exporting, and productivity dynamics. American Economic Review, 101(6), 1312-1344.

[11] Gallouj, F., \& Savona, M. (2009). Innovation in services: The review of the debate and a research agenda. Journal of Evolutionary Economics, 19(2), 149-172.

[12] Gault, F. (2010). Innovation Strategies for a Global Economy. Cheltenham, UK.

[13] Baczko, T. (2013). Raport o innowacyjności gospodarki Polski 2012 [Raport of Innovativeness of Polish Economy 2012], INE PAN, Warsaw.

[14] Szymańska, E. (2009). Innovativeness of Tourism Enterprises in Poland. Białystok: Publishing House of the Bialystok University of Technology.

[15] Szymańska, E. (2013). The Innovation Processes in Enterprises Which Render Services in the Scope of the Organisation of Tourism Events. Bialystok: Publishing House of the Bialystok University of Technology.

[16] Chesbrough, H. W. (2010). Business model innovation: Opportunities and barriers. Long Range Planning, 43, 354-363.

[17] Oliveira, P., \& Hippel, E. (2011). Users as service innovators: The case of banking services. Research Policy, 40, 806-818.

[18] Hollenstein, H. (2003). Innovation modes in the Swiss service sector: A cluster analysis based on firm-level data. Research Policy, 32, 845-863.

[19] Frenz, M., \& Letto-Gillies, G. (2009). The impact on innovation performance of different sources of knowledge: Evidence from the UK Community Innovation Survey. Research Policy, 38(7), 1125-1135.

[20] Tether, B. S., \& Tajar, A. (2008). The organizational-cooperation mode of innovation and its prominence amongst European service firm. Research Policy, 37(4), 720-739.

[21] Tether, B. S., \& Tajar, A. (2008). Beyond industry university links: Sourcing knowledge for innovation from consultants, private research organizations and the public science-base. Research Policy, 37, 1079-1095.

[22] Hjalager, A.-M. (1994). Dynamic innovation in the tourism industry. Progress in Tourism and Hospitality Management, 6, 197-224.

[23] Hjalager, A.-M. (1997). Innovation patterns in sustainable tourism - An analytical typology. Tourism Management, 18(1), 35-41.

[24] Hjalager, A.-M. (2009). Cultural tourism innovation systems - The Roskilde festival. Scandinavian Journal of Hospitality and Tourism, 9(2-3), 266-287.

[25] Hjalager, A.-M. (2005). Innovation in tourism in a welfare state perspective. Scandinavian Journal of Hospitality and Tourism, 5(1), 46-54.

[26] Hall, C. M., \& Williams, A. M. (2008). Tourism and Innovation. London: Rutlege.

[27] Kiryluk, H., \& Glińska, E. (2015). Creation and evaluation of the tourist image of a country - The example of Poland. Proceedings of 20th International Scientific Conference: Procedia - Social and Behavioral Sciences, 213, 671-676.

[28] Weiermair, K. (2006). Product improvement or innovation: What is the key to success in tourism? 
Innovation and Growth in Tourism. Paris:OECD.

[29] Turystyka. (2016). Retrieved from the website: www.turystyka.gov.pl

[30] Janasz, W., \& Kozioł K. (2007). The Determinants of the Corporate Innovation Activity. PWE, Warsaw.

[31] North, D. C. (2005). Understanding the Process of Economic Change. Princeton and Oxford: Princeton University Press.

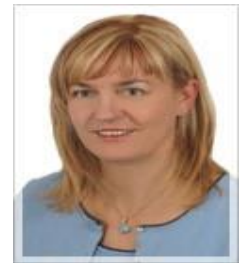

Elżbieta Szymańska is PhD, economist. Professor Elżbieta Szymańska is in Bialystok University of Technology, Poland, who is the president of the Tourism Economisc Chair at BUT and businesswoman and participant or manager of 16 research scientific projects. Professor Elżbieta Szymańska is an expert in foresight Poland 2020 and member of Polish Economy Association and Senator of Bialystok University of Technology (cadence 2016-2020). Professor Elżbieta Szymańska published 100 articles, including 5 books.

The major fields of study are as follows: SME development, management of innovations, tourism economics, sustainable tourism development, non-governmental organizations management. 